\title{
Circulation and Variability at the Southern Boundary of the Brazil Basin*
}

\author{
NELSON G. HoGG \\ Woods Hole Oceanographic Institution, Woods Hole, Massachusetts \\ Gerold Siedler AND Walter ZenK \\ Institut für Meereskunde an der Universität Kiel, Kiel, Germany
}

(Manuscript received 5 September 1997, in final form 12 February 1998)

\section{ABSTRACT}

\begin{abstract}
As a contribution to the WOCE Deep Basin Experiment, an array of current meters with individual record lengths exceeding $1 \frac{1}{2}$ years was set across the southern boundary of the Brazil Basin between early 1991 and early 1996. The array spanned the Santos Plateau, the Vema Channel, and the Hunter Channel, all areas believed to be important for transport of Antarctic Bottom Water between the Argentine and Brazil Basins. From the combination of geostrophic velocities computed from hydrographic stations and those directly measured, the total transport of bottom water (potential temperature below $2^{\circ} \mathrm{C}$ ) is estimated to be about $6.9 \mathrm{~Sv}\left(\mathrm{~Sv} \equiv 10^{6} \mathrm{~m}^{3}\right.$ $\mathrm{s}^{-1}$ ) northward, with about $4 \mathrm{~Sv}$ coming through the Vema Channel and the remainder through the Hunter Channel.

Properties of the eddy field are also discussed. Eddy energy levels and their spatial distribution are similar to comparable regimes in the North Atlantic. Integral timescales vary from a few days to several weeks with distance from the Brazil Current and the western boundary. The eddy heat flux is in the same direction as the heat advection by the mean flow but considerably smaller.
\end{abstract}

\section{Introduction}

The Deep Basin Experiment (DBE) of the World Ocean Circulation Experiment (WOCE) is an international program aimed at learning more about the deep circulation of the world's oceans through an intensive investigation of flow conditions within the Brazil Basin (Fig. 1). Particular objectives are to describe and quantify the circulation within the three major water masses of the subthermocline region, to estimate rates of diapycnal fluxes within the basin, and to investigate the processes that might control and modify the water entering and exiting the basin through its major connecting passages.

The DBE field program contains many elements. Figure 1 is a schematic view of these. A brief summary of the overall program is given by Hogg et al. (1996). In an attempt to quantify better the fluxes of mass, heat, and freshwater entering and leaving the basin, especially

\footnotetext{
* Woods Hole Oceanographic Institution Contribution Number 9558 .

Corresponding author address: Nelson G. Hogg, Clark Laboratory 3, Mail Stop \#21, Woods Hole Oceanographic Institution, Woods Hole, MA 02543-1541.

E-mail: nhogg@whoi.edu
}

with respect to the deepest layers, current meter arrays have been established at four locations believed to be the most important connectors to neighboring basins: two at the north end (an equatorial passage linking the Brazil Basin to the western North Atlantic, see Hall et al. 1997; and the Romanche-Chain Fracture Zones, see Mercier and Speer 1998) and two at the south end (the Vema and Hunter Channels).

This paper will report on observations pertinent to these last two locations, which result from a cooperative experiment between scientists and technicians from the Institut für Meereskunde at the Universität Kiel and the Woods Hole Oceanographic Institution. A description of the field program, along with some previously published results, is given in section 2 .

Section 3 will present a summary of the first moment of the horizontal velocity in the region (i.e., the means), as observed by the array, while section 4 will deal with the second moment quantities of eddy kinetic energy, eddy temperature flux, and integral timescale. A summary of results and their implications for the larger DBE program are given in section 5 .

\section{The southern boundary array}

In early 1991, on Meteor Cruise 15 (M15), an array of current meter moorings was set along a portion of 


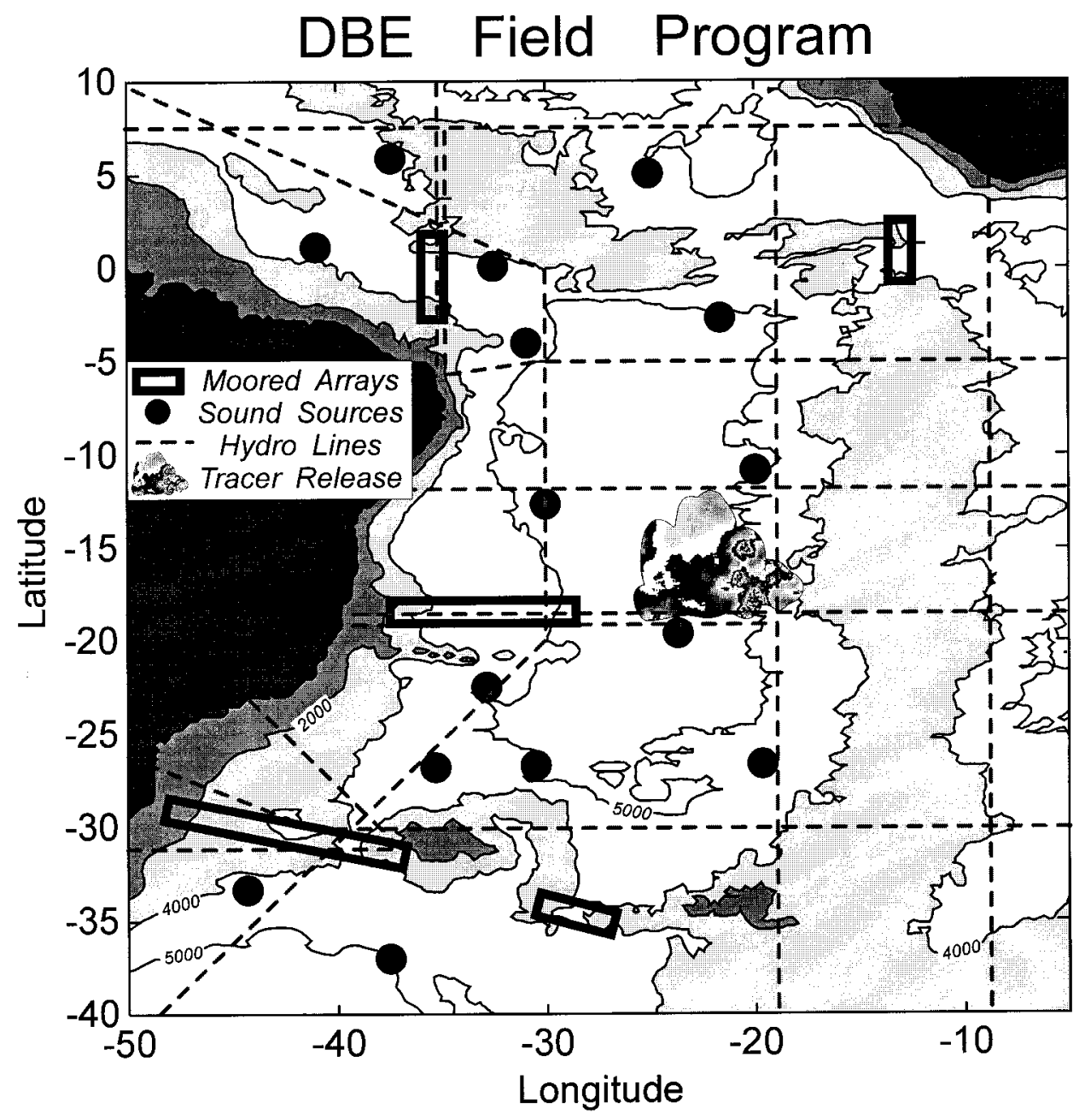

FIG. 1. Elements of the WOCE Deep Basin Experiment. This paper is concerned with observations collected from the boxes near $30^{\circ} \mathrm{S}$. The 2000-m, 4000-m, and 5000-m isobaths are shown. Adapted from Hogg et al. (1996).

the southern boundary of the Brazil Basin running from the lower continental slope over the Santos Plateau to the Vema Channel and the Rio Grande Plateau beyond (Fig. 2). When these were recovered almost 2 years later in late 1992 on Meteor Cruise 22 (M22), a subset of the instruments returned was refurbished and redeployed in the Hunter Channel farther to the east, a region of expected leakage of Antarctic Bottom Water (AABW) into the Brazil Basin (Burkle and Biscaye 1971; Speer et al. 1992). In their turn these instruments were recovered finally in May 1994 on Meteor Cruise 28 (M28). A single mooring, number 349, that had been set in a deep extension to the Vema Channel on M22 (as part of a sound source mooring for an associated RAFOS float program) was retrieved in March 1996 aboard Meteor 34. Details of instrument performance and vital statistics for the first deployment are given by Tarbell et al. (1994), for the second by Zenk and Müller (1995), and for the last (3-year deployment) by Zenk et al. (1996). Information pertinent to these moorings is to be found in Tables 1 and 2. All moored instruments measured the horizontal current vector and temperature; some measured pressure as well for purposes of monitoring mooring motion.

The first array was the most extensive and contained a total of 59 current measuring devices comprising 34 Aanderaa, 23 Vector Averaging Current Meters, and two Acoustic Doppler Current Profiler instruments on 13 moorings. Two moorings failed to release on command at recovery time but half of one of these was later retrieved through dragging. Various difficulties with the instruments limited data recovery to about $80 \%$ (Tarbell et al. 1994). The Hunter Channel moorings were all recovered, although instrument malfunctions restricted overall performance to about the $80 \%$ level once again. Mooring 349 was completely recovered in the Vema Extension and all instruments recorded current vectors properly but some of the temperature records are incomplete (Zenk et al. 1996).

A sample time series of measured current is shown 


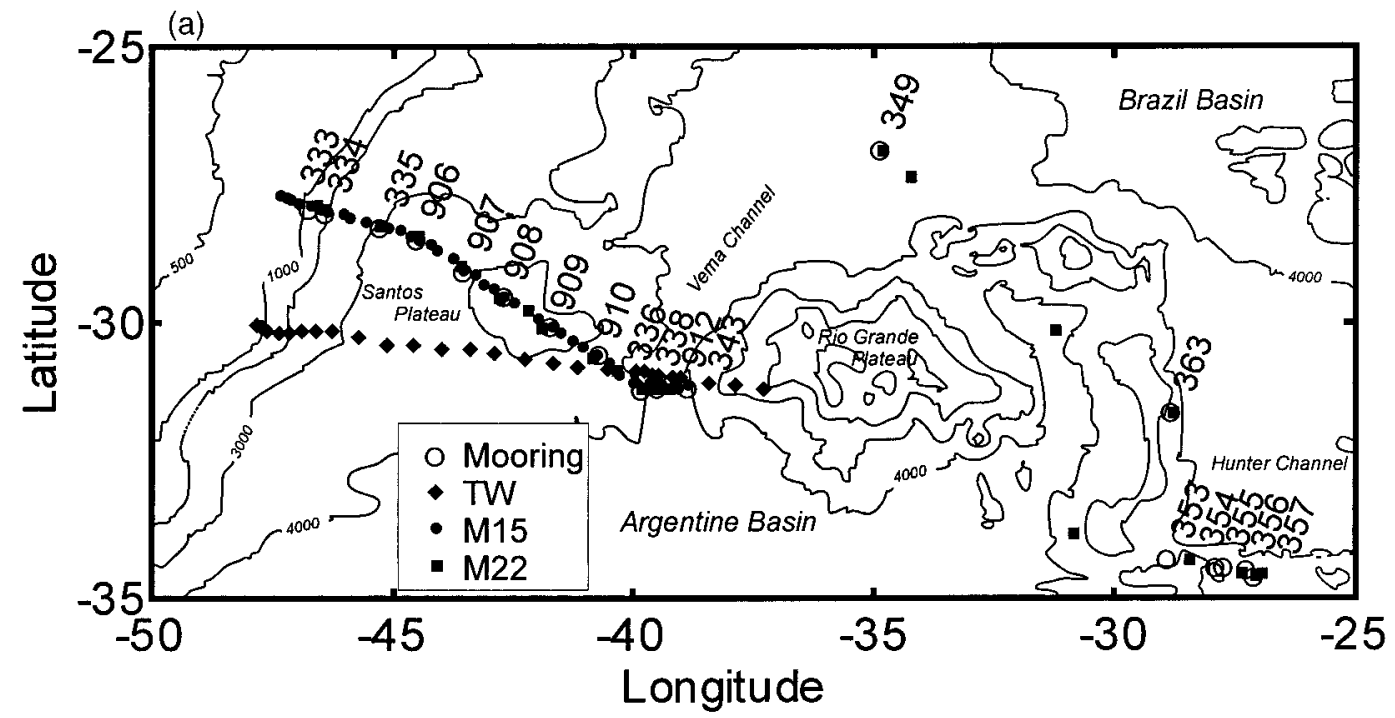

(b)

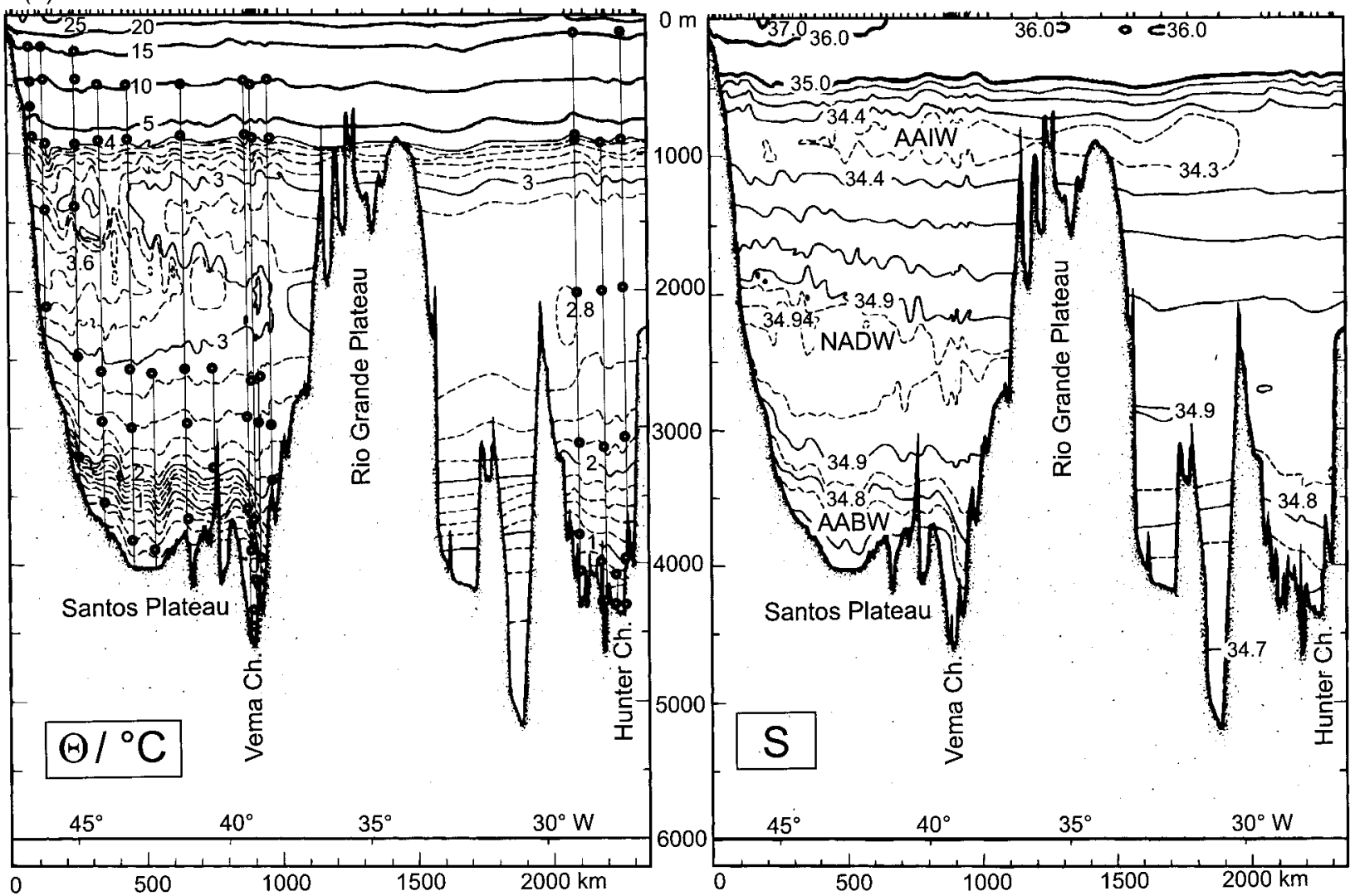

FIG. 2. Mooring and CTD locations along the southern boundary of the Brazil Basin. Moorings (open circles) numbered in the 300s were the responsibility of the IfM Kiel group while those in the 900s were designed and built by WHOI. (a) Plan view. (b) Sectional view with isotherms and isohalines from Meteor 15 superposed. Subthermocline water masses are abbreviated as follows: AAIW (Antarctic Intermediate Water), NADW (North Atlantic Deep Water), AABW (Antarctic Bottom Water). 
TABLE 1. Locations, setting dates, and some performance information for the current meters contained on the moorings shown in Fig. 2.

\begin{tabular}{|c|c|c|c|c|c|c|}
\hline Inst. & Setting date & $\begin{array}{l}\text { Number } \\
\text { of days }\end{array}$ & $\begin{array}{l}\text { Instrument } \\
\text { depth } \\
\text { (m) }\end{array}$ & $\begin{array}{l}\text { Lat } \\
\left({ }^{\circ} \mathrm{S}\right)\end{array}$ & $\begin{array}{l}\text { Long } \\
\left({ }^{\circ} \mathrm{W}\right)\end{array}$ & Comments \\
\hline 3332 & 4 Jan 1991 & 692 & 220 & -27.90 & -46.70 & Some large vertical excursions \\
\hline 3333 & & 692 & 460 & & & \\
\hline 3334 & & 692 & 670 & & & \\
\hline 3335 & & 692 & 875 & & & \\
\hline 3341 & 4 Jan 1991 & 692 & 280 & -27.99 & -46.34 & Some large vertical excursions \\
\hline 3342 & & 692 & 530 & & & \\
\hline 3343 & & 692 & 930 & & & \\
\hline 3344 & & 692 & 1430 & & & \\
\hline 3345 & & 692 & 2137 & & & \\
\hline 3352 & 5 Jan 1991 & 690 & 280 & -28.27 & -45.22 & Some large vertical excursions \\
\hline 3353 & & 645 & 550 & & & \\
\hline 3354 & & 690 & 950 & & & \\
\hline 3355 & & 690 & 1450 & & & \\
\hline 3356 & & 690 & 2445 & & & \\
\hline 3357 & & 690 & 3208 & & & \\
\hline 3361 & 19 Mar 1991 & 627 & 425 & -31.20 & -39.77 & \\
\hline 3362 & & 694 & 840 & & & \\
\hline 3363 & & 695 & 2970 & & & \\
\hline 3364 & & 575 & 3590 & & & Flooded, 2-month gap \\
\hline 3381 & 13 Jan 1991 & 692 & 520 & -31.14 & -39.43 & \\
\hline 3382 & & 692 & 900 & & & \\
\hline 3383 & & 692 & 2700 & & & \\
\hline 3384 & & 692 & 3850 & & & \\
\hline 3385 & & 692 & 4150 & & & \\
\hline 3386 & & 692 & 4425 & & & \\
\hline 3387 & & 692 & 4625 & & & \\
\hline 3432 & 1 Feb 1992 & 309 & 525 & -31.15 & -38.82 & 4 months of data \\
\hline 3434 & & 692 & 3025 & & & 8 months of data \\
\hline 3435 & & 692 & 3602 & & & \\
\hline 3491 & 18 Dec 1992 & 837 & 997 & -26.87 & -34.79 & No temperature data \\
\hline 3493 & & 837 & 4352 & & & \\
\hline 3494 & & 837 & 4849 & & & \\
\hline 3531 & 17 Dec 1992 & 520 & 175 & -34.26 & -28.87 & 3 months of temperature data \\
\hline 3534 & & 520 & 2025 & & & 7 months short \\
\hline 3535 & & 520 & 3125 & & & \\
\hline 3536 & & 520 & 3830 & & & \\
\hline 3537 & & 520 & 4105 & & & \\
\hline
\end{tabular}

in Fig. 3 from four moorings representing the Brazil Current (333, Fig. 3a), the Santos Plateau (909, Fig. 3b), the Vema Channel (338, Fig. 3c), and the Hunter Channel (358, Fig. 3d). The most similar are those from the Brazil Current (Fig. 3a) and the Vema Channel (Fig. $3 \mathrm{~d})$, as both are from regimes of persistently strong flows. The deeper instruments of the westernmost mooring (Fig. 3a) reveal relatively short timescales most likely associated with higher-frequency topographic waves over the slope. Motion over the Santos Plateau (Fig. 3b) is the least depth-dependent of the array. The Hunter Channel mooring (Fig. 3d) confirms the existence of a deep northward flow, with occasional reversals, transporting water from the Argentine to the Brazil Basin that was first suggested 25 years ago (Burkle and Biscaye 1971).

Conductivity-temperature-depth (CTD) stations were made at the mooring sites (as well as other locations) during each of the mooring operations cruises. The CTD data from the initial cruise (M15) and an assumed reference level of $2^{\circ} \mathrm{C}$ were used by Speer and
Zenk (1993) to calculate a transport of $6.7 \mathrm{~Sv}$ (1 Sv $\equiv$ $10^{6} \mathrm{~m}^{3} \mathrm{~s}^{-1}$ ) of AABW across the boundary into the Brazil Basin split in unequal portions between the Santos Plateau (2 Sv), the Vema Channel (3.9 Sv), and the Hunter Channel $(0.7 \mathrm{~Sv})$. In addition, they noted that the bottom water was significantly warmer on the 1992 M22 cruise than 2 years earlier: Zenk and Hogg (1996) and Hogg and Zenk (1997) discuss the long-term behavior of the bottom water temperature over the $25-\mathrm{yr}$ period that appropriate measurements have been made within the Vema Channel.

\section{First moments}

\section{a. Mean vectors}

For the purpose of summarizing the large amount of current meter data available we have chosen to divide the water column into five depth intervals that roughly correspond to the principal water masses (see Fig. 2b): 300-800 m (thermocline), 800-1200 m (Antarctic In- 
TABLE 1. (Continued)

\begin{tabular}{|c|c|c|c|c|c|c|}
\hline Inst. & Setting & $\begin{array}{l}\text { Number } \\
\text { of days }\end{array}$ & $\begin{array}{l}\text { Instrument } \\
\text { depth } \\
\text { (m) }\end{array}$ & $\begin{array}{l}\text { Lat } \\
\left({ }^{\circ} \mathrm{S}\right)\end{array}$ & $\begin{array}{l}\text { Long } \\
\left({ }^{\circ} \mathrm{W}\right)\end{array}$ & Comments \\
\hline 3541 & 18 Dec 1992 & 520 & 4000 & -34.42 & -27.86 & \\
\hline 3542 & & 520 & 4335 & & & \\
\hline 3551 & 19 Dec 1992 & 520 & 905 & -34.39 & -27.71 & \\
\hline 3552 & & 520 & 2005 & & & \\
\hline 3553 & & 520 & 3155 & & & \\
\hline 3554 & & 520 & 4310 & & & No current data \\
\hline 3561 & 21 Dec 1992 & 520 & 4100 & -34.51 & -27.32 & 1 month of current data \\
\hline 3571 & 21 Dec 1992 & 519 & 4048 & -34.58 & -27.06 & 2 sections, 6 months of data \\
\hline 3573 & & 519 & 4285 & & & 3 months of data \\
\hline 3582 & 21 Dec 1992 & 518 & 900 & -34.54 & -26.98 & \\
\hline 3583 & & 518 & 2000 & & & \\
\hline 3584 & & 518 & 3100 & & & \\
\hline 3585 & & 518 & 3980 & & & No current data \\
\hline 3586 & & 518 & 4310 & & & \\
\hline 3631 & 22 Dec 1992 & 514 & 3485 & -31.62 & -28.81 & \\
\hline 3632 & & 514 & 3705 & & & \\
\hline 9061 & 6 Jan 1991 & 573 & 509 & -28.47 & -44.47 & 3 months short \\
\hline 9062 & & 697 & 908 & & & \\
\hline 9063 & & 512 & 2609 & & & 4 months short \\
\hline 9065 & & 697 & 3532 & & & \\
\hline 9071 & 7 Jan 1991 & 659 & 496 & -29.04 & -43.49 & 2 months of current data \\
\hline 9072 & & 96 & 895 & & & 3 months of data \\
\hline 9073 & & 696 & 2595 & & & \\
\hline 9074 & & 696 & 2995 & & & \\
\hline 9075 & & 696 & 3850 & & & \\
\hline 9081 & 8 Jan 1991 & 696 & 2592 & -29.53 & -42.70 & \\
\hline 9082 & & 696 & 3918 & & & \\
\hline 9091 & 9 Jan 1991 & 695 & 514 & -30.09 & -41.74 & \\
\hline 9092 & & 695 & 914 & & & \\
\hline 9093 & & 695 & 2614 & & & \\
\hline 9095 & & 695 & 3714 & & & \\
\hline 9101 & 10 Jan 1991 & 771 & 2597 & -30.59 & -40.79 & \\
\hline 9121 & 13 Jan 1991 & 694 & 2587 & -31.08 & -39.16 & \\
\hline 9122 & & 694 & 2988 & & & \\
\hline 9123 & & 694 & 4060 & & & \\
\hline
\end{tabular}

termediate Water), 2000-3100 m (North Atlantic Deep Water), 3100-4100 m (upper AABW), and that greater than $4100 \mathrm{~m}$ (lower AABW flowing through the Vema and Hunter Channels). Although isotherms and isopycnals have consistent slopes downward to the east across our section, especially near the western boundary and within the Vema Channel (see Fig. 2b), the coarse vertical sampling of the moored array makes it impractical to be more refined in this grouping. Horizontal mean flow vectors with their standard errors shown as uncertainty ellipses in Fig. 4, were calculated assuming a 10-day decorrelation timescale, a subject to which we will return.

In the thermocline (Fig. 4a), as well as in the AAIW beneath (Fig. 4b), conditions at this latitude are dominated by the Brazil Current (Müller et al. 1998) and the anticyclonic subtropical gyre of the South Atlantic (Boebel et al. 1997): away from the strong western boundary current, flow is directed west-southwestward toward the coast with little apparent influence of the underlying topography. Flow within the NADW layer (Fig. 4c) is predominantly southward across the array but the topography is now seeming to exert some control: there is noticeable guiding and acceleration over the Vema Channel and splitting of the flow over a shallow depression in the Santos Plateau to the west. One exception to the southward flow is at the most inshore location where the velocity vector is northward, an observation to which we will return shortly.

As one might expect, the flow changes direction in the AABW layers to being mainly northward (Figs. 4d and $4 \mathrm{e}$ ), although there are some prominent exceptions. The flow just to east of the main part of the Vema Channel is southward, as was previously noted by Hogg et al. (1982), and could be part of a larger anticyclonic circulation around the Rio Grande Plateau or a return flow from the Brazil Basin. Over the Santos Plateau to the west of the Vema Channel there is apparent recirculation of bottom water exiting the Vema Channel around the shallow depression outlined by the 4000-m depth contour. Moving farther inshore the flow flipflops, first to the south and then back to the north.

The complex topography of the Hunter Channel region (Pätzold et al. 1996) prevents clear characterization of the flow there. Nevertheless the measured means are statistically significant and support the conclusions by 
TABLE 2. Some statistical information related to the horizontal velocities $\left(\mathrm{cm} \mathrm{s}^{-1}\right)$ and temperature $\left({ }^{\circ} \mathrm{C}\right)$ measured by the various current meters. Angle brackets indicate time averages. The third, fifth, and seventh columns $(\tau)$ give the integral timescale (in days) as defined in the text. Values are given only for time series longer than $1 \mathrm{yr}$ and have not been corrected for mooring motion. Shorter ones are indicated by "nc" for "not calculated."

\begin{tabular}{|c|c|c|c|c|c|c|c|c|c|c|c|c|}
\hline Inst. & $\langle u\rangle$ & $\tau_{u}$ & $\langle v\rangle$ & $\tau_{v}$ & $\langle t\rangle$ & $\tau_{t}$ & $\langle u u\rangle$ & $\langle v v\rangle$ & $\langle t t\rangle$ & $\langle u v\rangle$ & $\langle u t\rangle$ & $\langle v t\rangle$ \\
\hline 3332 & -14.3 & 5 & -25.9 & 10 & 16.9 & 8 & 159.9 & 362.8 & 2.04 & 45.67 & 0.223 & -1.161 \\
\hline 3333 & -8.5 & 3 & -13.5 & 9 & 11.1 & 6 & 45.3 & 138.1 & 0.92 & 15.00 & -0.391 & -1.140 \\
\hline 3334 & -3.3 & 2 & -5.1 & 7 & 6.9 & 9 & 22.2 & 100.1 & 0.41 & -5.41 & 0.329 & -1.980 \\
\hline 3335 & -1.8 & 2 & 0.8 & 7 & 4.6 & 6 & 8.7 & 122.7 & 0.07 & -10.13 & 0.122 & -1.428 \\
\hline 3341 & -6.0 & 7 & -8.4 & 7 & 15.3 & 8 & 133.0 & 157.8 & 3.66 & -15.16 & 3.577 & 6.958 \\
\hline 3342 & -5.0 & 7 & -6.1 & 8 & 10.4 & 9 & 58.5 & 79.2 & 2.26 & -4.26 & 1.867 & 2.686 \\
\hline 3343 & -2.5 & 4 & -3.0 & 7 & 4.5 & 9 & 25.0 & 41.0 & 0.07 & 1.47 & 0.050 & 0.055 \\
\hline 3344 & -1.3 & 4 & -2.9 & 7 & 3.5 & 10 & 11.7 & 33.0 & 0.01 & 7.06 & -0.023 & -0.035 \\
\hline 3345 & 0.3 & 3 & 1.2 & 4 & 3.6 & 9 & 8.7 & 29.3 & 0.01 & 12.34 & -0.052 & -0.065 \\
\hline 3352 & -1.3 & 23 & 1.2 & 8 & 15.2 & 12 & 183.4 & 113.3 & 1.50 & 23.20 & -3.632 & -2.532 \\
\hline 3353 & -1.8 & 18 & 1.0 & 8 & 10.3 & 19 & 71.1 & 36.9 & 1.07 & 13.22 & -2.324 & -1.066 \\
\hline 3354 & -1.3 & 23 & -0.5 & 6 & 4.3 & 11 & 28.0 & 10.9 & 0.04 & 0.70 & 0.041 & -0.036 \\
\hline 3355 & -3.6 & 19 & -1.6 & 7 & 3.3 & 29 & 24.3 & 22.1 & 0.03 & 2.26 & 0.130 & -0.139 \\
\hline 3356 & -2.3 & 8 & -1.4 & 8 & 3.2 & 23 & 9.8 & 27.5 & 0.00 & 0.77 & -0.051 & -0.027 \\
\hline 3357 & 1.7 & 4 & 4.6 & 5 & 1.2 & 8 & 7.9 & 42.6 & 0.11 & 14.51 & -0.322 & -0.979 \\
\hline 3361 & -3.5 & 43 & 1.1 & 21 & 12.5 & 53 & 42.7 & 33.0 & 0.23 & -6.50 & -1.151 & 0.460 \\
\hline 3362 & -1.6 & 27 & -0.3 & 21 & 5.0 & 57 & 11.7 & 10.2 & 0.10 & -2.43 & -0.458 & -0.065 \\
\hline 3363 & 0.3 & 9 & 0.5 & 14 & 2.8 & 39 & 5.0 & 24.7 & 0.00 & -5.98 & -0.007 & 0.061 \\
\hline 3364 & -1.6 & 8 & 3.8 & 11 & 1.3 & 11 & 5.7 & 19.0 & 0.05 & -8.53 & 0.146 & -0.286 \\
\hline 3381 & -3.3 & 40 & 0.4 & 22 & 9.3 & 34 & 40.0 & 25.3 & 0.50 & -8.51 & -1.199 & -0.046 \\
\hline 3382 & -1.5 & 27 & 0.0 & 17 & 4.0 & 40 & 10.3 & 9.8 & 0.04 & -3.89 & -0.148 & -0.009 \\
\hline 3383 & 1.1 & 13 & -2.3 & 12 & 3.1 & 32 & 8.9 & 13.8 & 0.00 & -6.21 & 0.043 & -0.062 \\
\hline 3384 & -1.9 & 7 & 3.5 & 10 & 1.2 & 8 & 23.8 & 43.0 & 0.02 & -21.65 & 0.262 & -0.418 \\
\hline 3385 & -11.8 & 7 & 13.5 & 9 & 0.4 & 10 & 67.1 & 43.4 & 0.02 & -46.54 & -0.009 & -0.124 \\
\hline 3386 & -13.2 & 10 & 33.7 & 8 & 0.2 & 11 & 18.6 & 72.5 & 0.00 & -34.07 & 0.017 & -0.021 \\
\hline 3387 & -6.8 & 7 & 29.3 & 9 & 0.2 & 38 & 2.8 & 82.2 & 0.00 & -9.27 & 0.001 & -0.031 \\
\hline 3432 & nc & $\mathrm{nc}$ & $\mathrm{nc}$ & nc & $\mathrm{nc}$ & $\mathrm{nc}$ & nc & nc & nc & nc & $\mathrm{nc}$ & $\mathrm{nc}$ \\
\hline 3434 & -1.3 & 9 & -0.6 & 13 & 2.4 & 36 & 7.1 & 9.4 & 0.00 & -2.59 & -0.001 & 0.053 \\
\hline 3435 & -0.4 & 3 & -4.3 & 12 & 1.9 & 23 & 4.3 & 25.3 & 0.03 & -1.50 & -0.022 & 0.467 \\
\hline 3491 & -1.0 & 16 & -0.4 & 10 & $\mathrm{nc}$ & $\mathrm{nc}$ & 6.5 & 11.8 & nc & -2.29 & nc & nc \\
\hline 3493 & 5.1 & 10 & 1.7 & 4 & 0.8 & 15 & 34.1 & 9.8 & 0.03 & 9.59 & 0.265 & 0.181 \\
\hline 3494 & 12.0 & 12 & 4.5 & 9 & 0.8 & 113 & 81.7 & 11.7 & 0.01 & 28.55 & 0.052 & 0.021 \\
\hline 3531 & -5.1 & 38 & -3.1 & 22 & $\mathrm{nc}$ & $\mathrm{nc}$ & 74.6 & 53.4 & nc & 9.58 & $\mathrm{nc}$ & $\mathrm{nc}$ \\
\hline 3534 & $\mathrm{nc}$ & $\mathrm{nc}$ & nc & nc & 2.9 & 21 & $\mathrm{nc}$ & nc & 0.00 & $\mathrm{nc}$ & $\mathrm{nc}$ & $\mathrm{nc}$ \\
\hline 3535 & -1.1 & 52 & 0.2 & 13 & 2.5 & 49 & 3.5 & 3.0 & 0.00 & -2.01 & 0.002 & 0.002 \\
\hline 3536 & -0.5 & 3 & 0.5 & 5 & $\mathrm{nc}$ & $\mathrm{nc}$ & 2.3 & 2.3 & $\mathrm{nc}$ & -1.94 & $\mathrm{nc}$ & nc \\
\hline 3537 & -0.9 & 1 & 0.5 & 0 & 1.0 & 8 & 7.1 & 3.8 & 0.00 & -4.15 & -0.056 & 0.040 \\
\hline 3541 & -0.3 & 4 & 1.6 & 24 & 1.0 & 64 & 1.2 & 5.7 & 0.01 & -0.57 & 0.020 & -0.156 \\
\hline 3542 & 1.3 & 2 & 0.4 & 8 & 0.7 & 26 & 1.1 & 4.8 & 0.00 & 0.35 & -0.014 & -0.054 \\
\hline 3551 & -0.7 & 24 & 0.5 & 15 & 3.9 & 22 & 9.1 & 6.6 & 0.02 & 1.74 & -0.055 & -0.090 \\
\hline 3552 & -0.6 & 31 & -0.2 & 13 & 2.9 & 16 & 3.0 & 2.0 & 0.00 & 0.81 & 0.009 & -0.001 \\
\hline 3553 & -0.2 & 19 & 0.1 & 11 & 2.6 & 27 & 3.6 & 3.6 & 0.00 & 1.05 & 0.000 & 0.004 \\
\hline 3554 & nc & $\mathrm{nc}$ & nc & $\mathrm{nc}$ & 0.6 & 35 & nc & nc & 0.01 & nc & $\mathrm{nc}$ & nc \\
\hline 3561 & nc & $\mathrm{nc}$ & nc & $\mathrm{nc}$ & 1.0 & 62 & nc & nc & 0.01 & nc & $\mathrm{nc}$ & nc \\
\hline 3571 & nc & $\mathrm{nc}$ & nc & $\mathrm{nc}$ & 1.3 & 20 & nc & nc & 0.01 & nc & $\mathrm{nc}$ & nc \\
\hline 3573 & nc & $\mathrm{nc}$ & nc & nc & 0.9 & 17 & nc & nc & 0.01 & nc & $\mathrm{nc}$ & $\mathrm{nc}$ \\
\hline 3582 & 0.3 & 18 & 0.0 & 7 & 4.0 & 48 & 2.9 & 4.6 & 0.03 & -0.25 & 0.022 & -0.084 \\
\hline 3583 & -0.1 & 14 & -0.1 & 10 & 2.8 & 15 & 2.0 & 1.5 & 0.00 & 0.01 & -0.003 & -0.001 \\
\hline 3584 & -1.0 & 10 & -0.8 & 15 & 2.6 & 18 & 2.6 & 4.9 & 0.00 & 0.44 & 0.015 & 0.015 \\
\hline 3585 & nc & $\mathrm{nc}$ & $\mathrm{nc}$ & nc & 1.3 & 9 & $\mathrm{nc}$ & nc & 0.00 & $\mathrm{nc}$ & nc & nc \\
\hline 3586 & 4.8 & 2 & 4.3 & 1 & 0.6 & 33 & 12.0 & 8.4 & 0.00 & 9.31 & -0.048 & -0.045 \\
\hline 3631 & -0.3 & 9 & -1.5 & 24 & 2.1 & 24 & 3.3 & 10.9 & 0.01 & 2.44 & -0.053 & -0.183 \\
\hline 3632 & 1.2 & 2 & -0.2 & 19 & 1.5 & 35 & 2.7 & 2.0 & 0.01 & 0.99 & -0.016 & -0.019 \\
\hline 9061 & -2.5 & 18 & 0.2 & 13 & 11.0 & 19 & 54.8 & 40.2 & 0.79 & -0.19 & -1.513 & -1.735 \\
\hline 9062 & -4.2 & 14 & 0.6 & 22 & 4.4 & 16 & 26.7 & 17.8 & 0.07 & 2.87 & -0.144 & -0.378 \\
\hline 9063 & -5.3 & 11 & -0.2 & 8 & 3.1 & 9 & 31.9 & 32.6 & 0.00 & 13.04 & 0.093 & 0.025 \\
\hline
\end{tabular}


TABLE 2. (Continued)

\begin{tabular}{|c|c|c|c|c|c|c|c|c|c|c|c|c|}
\hline Inst. & $\langle u\rangle$ & $\tau_{u}$ & $\langle v\rangle$ & $\tau_{v}$ & $\langle t\rangle$ & $\tau_{t}$ & $\langle u u\rangle$ & $\langle v v\rangle$ & $\langle t t\rangle$ & $\langle u v\rangle$ & $\langle u t\rangle$ & $\langle v t\rangle$ \\
\hline 9065 & -0.6 & 8 & -1.1 & 8 & 0.9 & 26 & 26.2 & 18.4 & 0.02 & 9.78 & 0.094 & -0.018 \\
\hline 9071 & $\mathrm{nc}$ & nc & $\mathrm{nc}$ & $\mathrm{nc}$ & 11.1 & 16 & nc & $\mathrm{nc}$ & 0.58 & $\mathrm{nc}$ & nc & $\mathrm{nc}$ \\
\hline 9702 & nc & $\mathrm{nc}$ & nc & $\mathrm{nc}$ & $\mathrm{nc}$ & $\mathrm{nc}$ & $\mathrm{nc}$ & $\mathrm{nc}$ & $\mathrm{nc}$ & $\mathrm{nc}$ & $\mathrm{nc}$ & $\mathrm{nc}$ \\
\hline 9073 & -3.0 & 8 & 1.5 & 5 & 3.1 & 12 & 46.5 & 29.0 & 0.00 & 3.86 & 0.047 & 0.018 \\
\hline 9074 & -2.6 & 8 & 2.0 & 5 & 2.8 & 10 & 54.4 & 38.8 & 0.01 & 3.58 & 0.112 & 0.079 \\
\hline 9075 & 1.0 & 5 & 4.7 & 6 & 0.6 & 19 & 33.9 & 42.9 & 0.00 & -7.84 & 0.074 & -0.077 \\
\hline 9081 & -1.5 & 10 & 0.2 & 4 & 3.1 & 11 & 29.0 & 21.0 & 0.00 & 0.47 & -0.032 & 0.013 \\
\hline 9082 & 0.0 & 10 & -0.1 & 4 & 0.6 & 11 & 41.4 & 28.9 & 0.00 & 1.58 & 0.005 & 0.105 \\
\hline 9091 & -2.8 & 13 & -0.8 & 16 & 11.0 & 41 & 12.8 & 25.1 & 0.38 & -1.72 & -0.516 & 1.083 \\
\hline 9092 & -2.2 & 13 & -0.6 & 16 & 4.5 & 21 & 5.6 & 11.3 & 0.05 & -1.53 & -0.129 & 0.044 \\
\hline 9093 & 0.9 & 14 & -1.5 & 20 & 3.1 & 13 & 14.0 & 16.5 & 0.00 & -1.52 & -0.005 & 0.023 \\
\hline 9095 & -0.2 & 3 & -2.1 & 4 & 0.9 & 19 & 7.0 & 7.7 & 0.02 & -2.11 & -0.049 & -0.008 \\
\hline 9101 & -0.1 & 17 & -1.0 & 19 & 3.1 & 29 & 9.3 & 11.7 & 0.00 & -0.20 & 0.049 & -0.048 \\
\hline 9121 & 0.6 & 10 & -0.9 & 11 & 3.1 & 43 & 7.2 & 12.5 & 0.00 & -3.72 & 0.012 & -0.005 \\
\hline 9122 & 0.9 & 8 & -1.4 & 10 & 2.8 & 41 & 10.7 & 14.8 & 0.00 & -3.68 & 0.011 & -0.007 \\
\hline 9123 & 0.6 & 5 & -1.0 & 4 & 1.0 & 7 & 6.3 & 11.4 & 0.02 & 0.63 & -0.043 & -0.110 \\
\hline
\end{tabular}

Burkle and Biscaye (1971) and Speer et al. (1992) that this is a conduit for some exchange between the Argentine and Brazil Basins: Speer and Zenk (1993) estimated $0.7 \mathrm{~Sv}$ based on a single hydrographic section (but see below).

Near the western boundary, the isopycnals slope strongly (cf. Fig. 2b) and the separation into depth layers, as above, can be confusing. A vertical cross-section view of the component of the mean flow crossing the mooring section (Fig. 5a) helps to clarify some of the anomalies of Fig. 4. Here we see the Brazil Current as a western boundary current that, in the mean, extends to the bottom of the ocean near $45^{\circ} \mathrm{W}$. This penetration to the bottom splits the generally northward flowing AABW over the Santos Plateau. At greater depths there is prominent northward flow through both the Vema and Hunter Channels with the former being more intense than the latter.

\section{b. AABW transport}

Part of the rationale for the moored array was that it would provide direct current measurements and help quantify bottom-water fluxes into the Brazil Basin. Previous work in this region was based almost entirely on hydrographic data and the associated use of water mass boundaries such as that between NADW and AABW to define a surface of no motion. For example, Zemba (1991) used the $45.85 \sigma_{4}$ isopycnal in her work quantifying fluxes through a series of four sections emanating from the western boundary in the southern Brazil and northern Argentine Basins that were obtained in late 1984 on the R/V Thomas Washington Marathon Cruise (TW). One of these sections is just south of the M15 and M22 sections (Fig. 2a) and the velocity section resulting from the dynamic computations (Fig. 5b) shows bottom-water flow that is almost uniformly northward. Zemba reports a total northward transport of AABW of $4.3 \mathrm{~Sv}$ with just $0.2 \mathrm{~Sv}$ flowing over the
Santos Plateau and the remainder (4.1 Sv) through the Vema Channel.

Speer and Zenk (1993) used the $2^{\circ} \mathrm{C}$ potential temperature isotherm for referencing the velocity computation. This is nearly coincident with the $45.85 \sigma_{4}$ isopycnal and, along the M15 and M22 transects, slopes almost uniformly downward to the east with steepening near the western boundary and within the Vema Channel (Fig. 2b). The cumulative transport curves (Fig. 6) for both M15 and M22 show most of the contribution coming from these two regions: M15 gives a total of 5.9 $\mathrm{Sv}$ with $1.3 \mathrm{~Sv}$ coming from the Santos Plateau while M22 gives $3.8 \mathrm{~Sv}$ and $1.8 \mathrm{~Sv}$ from the plateau. Our recalculation of the TW section, using the $2^{\circ} \mathrm{C}$ reference level, gives a slightly larger number than Zemba's: 4.9 $\mathrm{Sv}$ with $0.3 \mathrm{~Sv}$ from the plateau region.

These dynamic computations present two quandaries. First, how does the weak northward transport (0.2-0.3 $\mathrm{Sv}$ ) computed for the plateau region in the TW survey become much larger (1.3-1.8 Sv) for the Meteor cruises? Second, why does the Vema Channel transport decrease by a factor of 2 by the time of the M22 cruise? Answers to both of these questions can be found in the direct current measurements.

Although the current meter moorings are somewhat sparsely distributed, we have attempted to combine the direct velocity measurements over the Santos Plateau with the dynamic computations to improve the transport estimate in this region. Inspection of the mean vectors (Fig. 4d) and the velocity section (Fig. 5a) shows flows that are not compatible with either of the above choices for a zero velocity surface: rather than uniform northward flow we see two regions of southward flow (note, however, that the sense of the shear is generally consistent with that indicated by the slope of the $2^{\circ} \mathrm{C}$ isotherm).

CTD station pairs were chosen to straddle each mooring position and the reference velocity for each pair was determined by minimizing the differences between the 
(a)

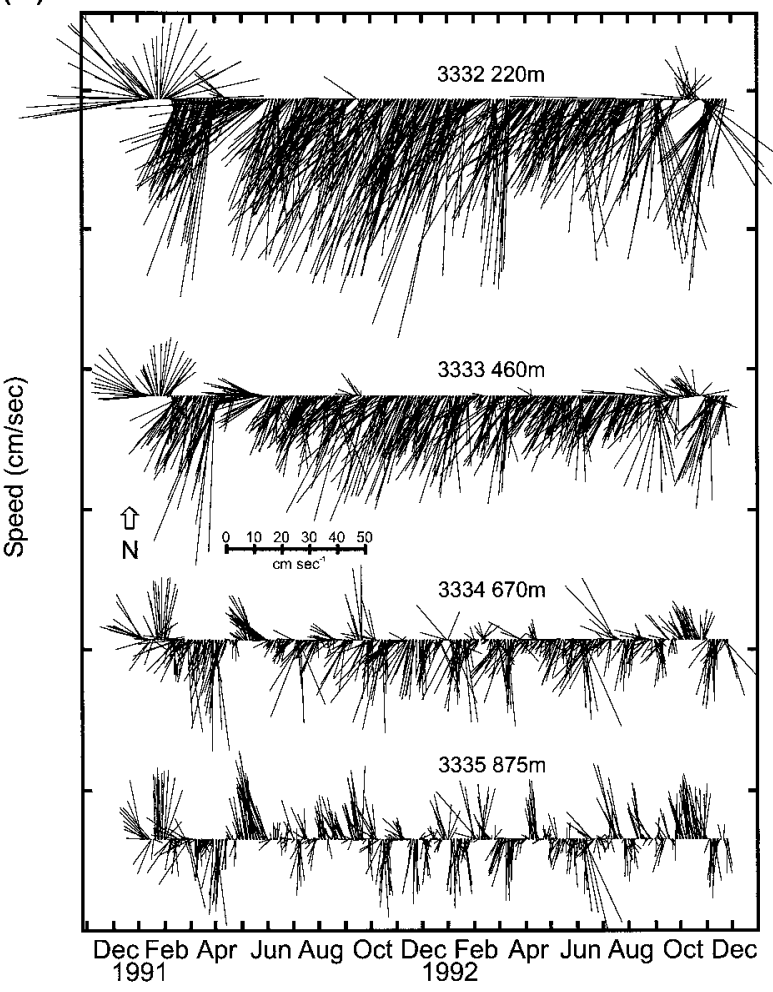

(c)

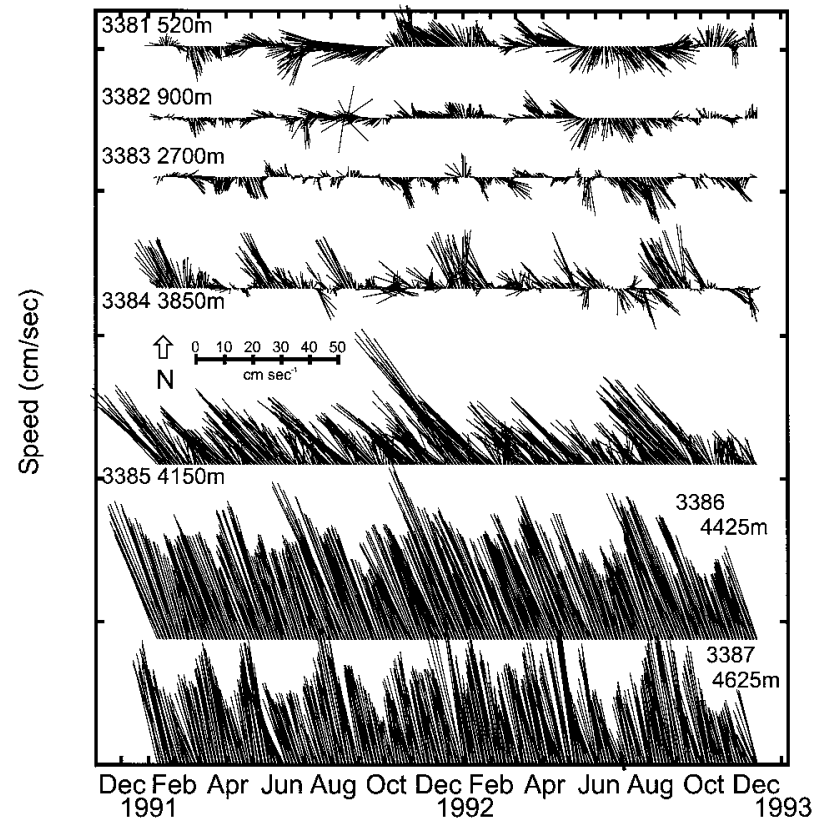

(b)

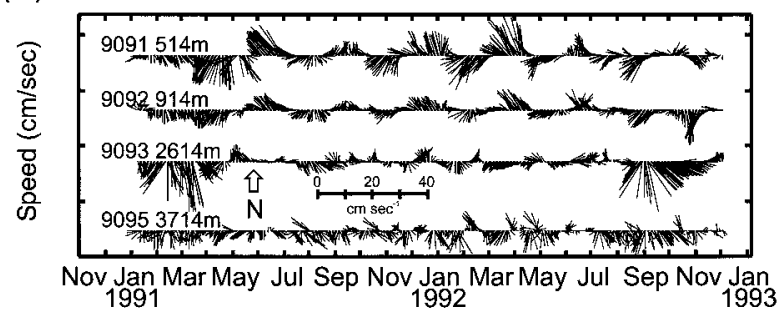

(d)

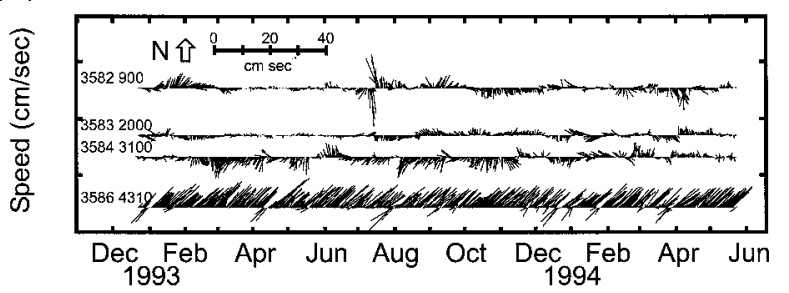

FIG. 3. Vector horizontal velocities as a function of time at moorings (a) 333 within the Brazil Current, (b) 909 over the Santos Plateau, (c) 338 in the Vema Channel, and (d) 358 in the Hunter Channel. All are plotted to the same scale, with north being up, and all have been low-pass filtered to remove frequencies higher than $44 \mathrm{~h}$. To the left of each time series the instrument number and depth (m) are indicated.

velocities calculated using the dynamic method and those measured directly (through-section components), in a least squares sense. As this paper focuses on the deep and bottom water and the eddy signal is strongest near the surface, we decided to restrict this fit to those instruments that were deeper than $1000 \mathrm{~m}$. Multiplying the resulting reference velocities by areas defined by the region below $2^{\circ} \mathrm{C}$ and between nearest neighbors, and then summing, yields cumulative barotropic transport curves for M15 and M22 (Fig. 6). The total transport of AABW is then the sum of the baroclinic and barotropic contributions. In this melding of hydrographic and direct velocity measurements we compared dynamically computed velocity profiles with discrete measurements that had been low-pass filtered in three ways: the first (M15) or last (M22) day of series filtered with 44-h and 5-day half-power points and the record means (Table 3). With the exception of the computation using the record mean in combination with the M22 hydrographic data there is a strong indication that the northward 1.3-1.8 Sv geostrophic transport with respect to $2^{\circ} \mathrm{C}$ is nullified by a comparable southward barotropic one. We conclude that, upon emerging from the Vema Channel, shallow components of the AABW recirculate over the Santos Plateau north of the TW section and there is very little, if any, net flow over the plateau.

In the above calculation the M22 result is the most questionable as hydrographic stations were made only at the mooring sites, thus making the comparison between dynamic calculations and direct measurements 


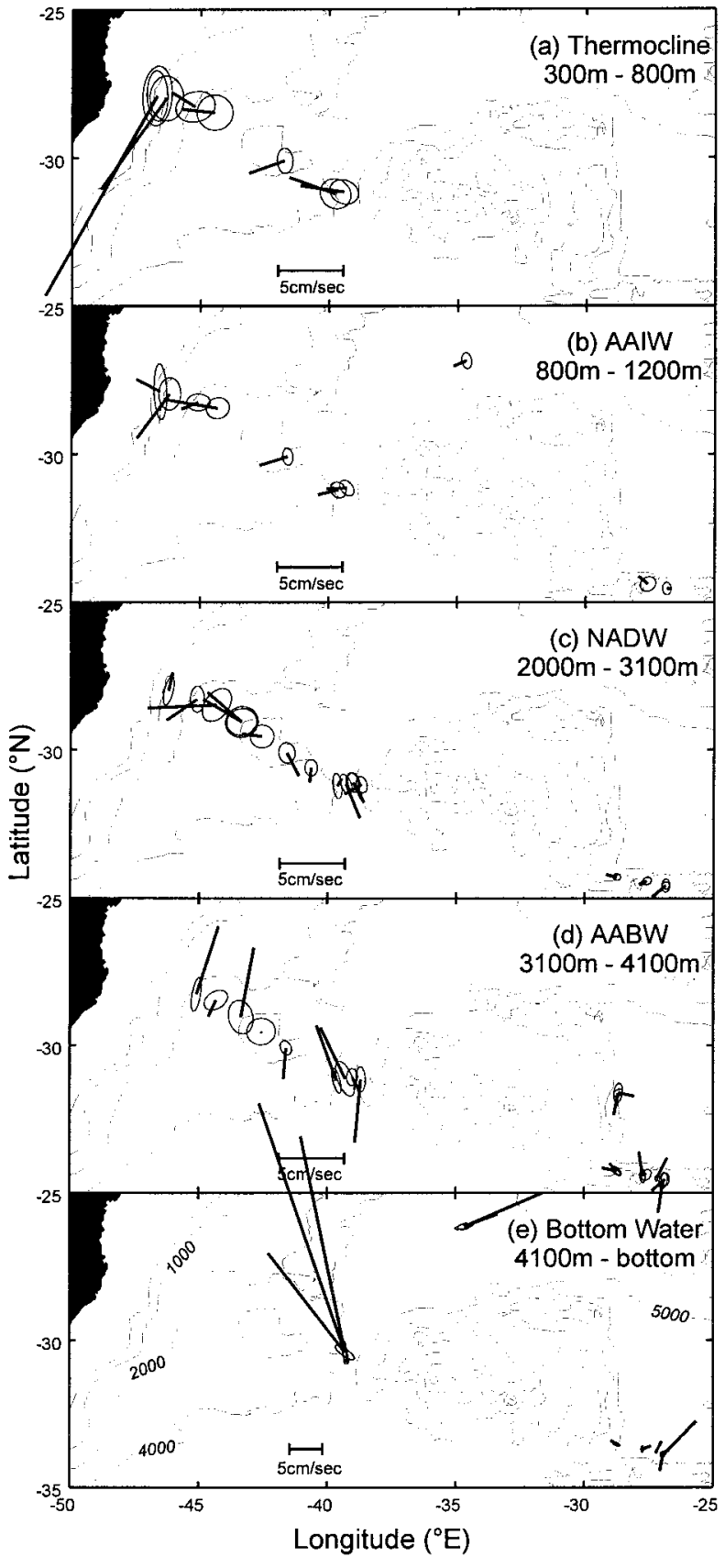

FIG. 4. Mean flow vectors with standard error ellipse at various depth intervals superposed on bathymetry. The error ellipse is calculated from the velocity variance ellipse reduced in size by the square root of the number of degrees of freedom (record length in days divided by 10). (a) 300-800 $\mathrm{m}$ (the thermocline region), (b) 800-1200 m (the Antarctic Intermediate Water layer), (c) 2000-3100 m (North Atlantic Deep Water), (d) 3100-4100 m (Antarctic Bottom Water), and (e) 4100 m-bottom (deep channel flows).

more difficult. In addition, M22 being the recovery cruise, fewer data were available because of instrument failures. We chose to compute the geostrophic velocities from the widely spaced station pairs that spanned the mooring (ignoring that at the mooring site) and used the 5-day low-pass filter on the time series.

This leaves the Vema Channel as the major conduit west of the Rio Grande Plateau for AABW exchange between the Brazil and Argentine Basins. Based on 18month records from four current meter moorings spanning the channel in 1979-1980, Hogg et al. (1982) have estimated the AABW transport to be $4.0 \mathrm{~Sv}$ with a standard deviation of $\pm 1.2 \mathrm{~Sv}$ (error of the mean, though, is $\pm 0.4 \mathrm{~Sv}$ ). None of the three estimates that result from the dynamic computations discussed above differs significantly from this estimate. The smallest is the $2 \mathrm{~Sv}$ coming from the M22 data, which Hogg and Zenk (1997) suggest might be associated with their documented warming of the bottom water. The minimum calculated by Hogg et al. (1982) is near zero and occurred for a brief period when a deep eddy appeared to reverse the northward flow. In Holfort (1994) an estimate of the Vema Channel transport is made from the mooring data collected by three moorings located in the channel between the M15 and M22 cruises. By multiplying the mean meridional components by appropriate cross-sectional areas below $2^{\circ} \mathrm{C}$ around current meters, he sums the results to obtain 5.1-5.3 Sv depending on the choice of cross-sectional areas.

Data from the partial redeployment of current meters in the Hunter Channel have only recently been analyzed (Lenz 1997). Transport estimates of bottom water $\left(<2^{\circ} \mathrm{C}\right)$ from moored current meters amount to $2.9 \pm$ $1.3 \mathrm{~Sv}$ in this case and indicate a mean equatorward net transport of $\mathrm{AABW}$ roughly three times larger than the previously inferred geostrophic transport estimates.

Property fluxes through deep passages have been used to estimate average mixing rates in the downstream basins (e.g., Whitehead and Worthington 1982; Hogg et al. 1982; Saunders 1987; Roemmich et al. 1996) and to constrain inversions of hydrographic data (e.g., Rintoul 1991). For these purposes we include Table 4, a summary of the volume, heat, and salt fluxes for the AABW west of the Rio Grande Plateau, subdivided into four temperature ranges.

\section{Second moments}

We will summarize the properties of the second moments with computations of the eddy kinetic energy (Fig. 7), the eddy temperature flux (Fig. 8), and the integral timescales for the horizontal velocity components (Fig. 9).

The distribution of eddy kinetic energy per unit mass (Fig. 7) is not surprising: it is a maximum in regions of strongest mean flow (the Brazil Current and Vema Channel) and weakest well away from these areas where values fall to just a few $\mathrm{cm}^{2} \mathrm{~s}^{-2}$. It is generally surface intensified, although only weakly so just offshore of the Brazil Current (moorings 906-909). There is a deep maximum sitting over the shallow depression on the Santos Plateau near $43^{\circ} \mathrm{W}$, probably resulting from to- 

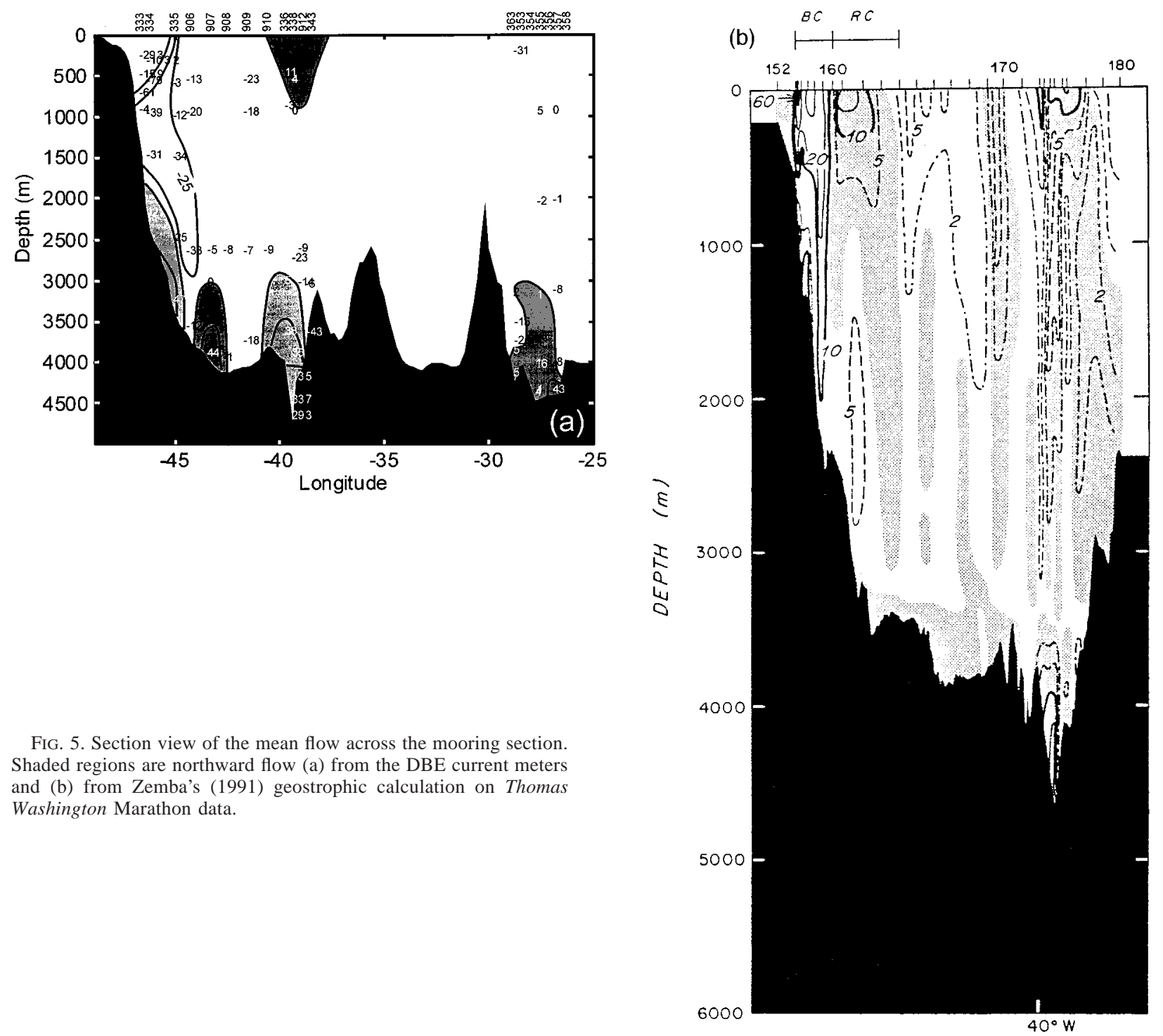

FIG. 5. Section view of the mean flow across the mooring section. Shaded regions are northward flow (a) from the DBE current meters and (b) from Zemba's (1991) geostrophic calculation on Thomas Washington Marathon data.

pographic wave activity (Spall 1994) in this region (see Fig. 3b). These are all characteristics of the eddy field that we have come to associate with western boundary regimes of the world's oceans. The eddy variance is lower in the Vema Channel than in the Brazil Current even though the mean speeds in these areas are similar (Fig. 5a) because of the strong contraints imposed by the channel geometry.

Eddy temperature fluxes (Fig. 8) are more variable in space than the corresponding mean flows (Fig. 4). In the upper two depth ranges they are mostly directed southward so that the flux by eddies in the upper ocean enhances that by the mean flow, which is carrying warm water southward in this westward limb of the subtropical gyre. Eddy temperature flux is weakest in the NADW layer (2000-3100 m), reflecting the relative homogeneity of this part of the water column. For the bottom layer, eddy temperature flux opposes the mean velocity vectors: given that the mean temperature perturbation for this layer is negative we see that, once again, the eddy temperature flux is directed so as to enhance the temperature flux by the mean flow.

The magnitude of the eddy flux is generally low. For example, if we take the value of $1^{\circ} \mathrm{C} \mathrm{cm} \mathrm{s}^{-1}$ to be representative of the $\mathrm{AABW}$ layer and multiply it by an estimate of the area to the west of the Vema Channel (e.g., $1500 \mathrm{~m}$ deep by $700 \mathrm{~km}$ wide), the density, and the specific heat, we obtain the value of $-0.04 \mathrm{PW}$, not a large value but one comparable to estimates of the contribution to the total heat transport by the mean flow for this layer (M. Vanicek 1996, personal communication). It is also a modest fraction of $0.25 \mathrm{PW}$ - the total, zonally integrated, heat flux estimated by Rintoul (1991) at $32^{\circ} \mathrm{S}$. 


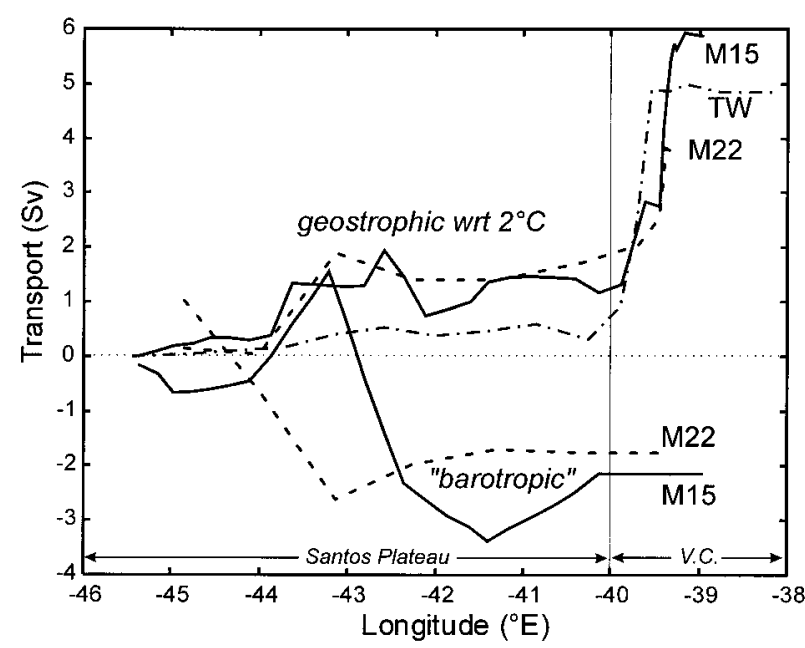

FIG. 6. Components of the integrated transport of AABW over the Santos Plateau for the Marathon (TW), Meteor 15 and Meteor 22 cruises, all done with respect to a zero velocity surface at $2^{\circ} \mathrm{C}$. The eastern edge of the Santos Plateau at the Vema Channel is near $40^{\circ} \mathrm{W}$ and is indicated by the thin vertical line. The barotropic transport is defined as that contributed (below $2^{\circ} \mathrm{C}$ ) by the reference level velocity, which has been determined by a least squares fit of the geostropic profile to the measured through-section velocity component.

The uncertainties in the mean flow vectors shown in Fig. 4 were calculated using a uniform value of 10 days for the integral time scale (meaning that the number of degrees of freedom is obtained by dividing the record length, in days, by 20 days or twice the integral timescale), a value derived from experience in the corresponding North Atlantic regime (e.g., Hogg 1983). Figure 9 shows an estimate of the integral timescale, with this dataset, for both horizontal velocity components: to be precise, the numbers displayed and contoured in Fig. 9 are the discrete integral of the time-lagged correlation function from zero lag to the first zero crossing. This can be considered a conservative estimate for it neglects the usually significant negative correlations beyond the first crossing through zero. For both components, timescales range from just a few days along the continental slope and rise where short period motions dominate, to longer than 20 days in the interior thermocline. For much of the NADW and AABW layers an integral timescale of 5-15 days is indicated.

TABLE 3. Contribution to the transport of AABW over the Santos Plateau by the reference level velocity, in Sverdrups. The reference level velocity was determined by a least squares fit of current meter measurements, low-pass filtered or averaged over the indicated number of days, to geostrophic velocity profiles calculated from hydrographic data collected on the indicated cruises.

\begin{tabular}{cccc}
\hline \hline Meteor cruise & 1-day & 5-day & Record mean \\
\hline 15 & -3.9 & -2.1 & -1.3 \\
22 & -0.2 & -1.8 & 1.4 \\
\hline
\end{tabular}

TABLE 4. AABW fluxes of volume, temperature and salt for the Santos Plateau-Vema Channel section. Temperature flux is relative to $0^{\circ} \mathrm{C}$ and salt flux is relative to $34 \mathrm{psu}$. These numbers result from the combination of Meteor 15 hydrographic data and the moored current meter data, as described in the text.

\begin{tabular}{|c|c|c|c|}
\hline \multirow{2}{*}{$\begin{array}{c}\text { Temperature } \\
\text { range } \\
\left({ }^{\circ} \mathrm{C}\right)\end{array}$} & \multicolumn{3}{|c|}{ Fluxes of } \\
\hline & $\begin{array}{l}\text { Volume } \\
\text { (Sv) }\end{array}$ & $\begin{array}{c}\text { Temperature } \\
\left({ }^{\circ} \mathrm{C} \mathrm{Sv}\right)\end{array}$ & $\begin{array}{c}\text { Salt } \\
(\mathrm{psu} \text { Sv) }\end{array}$ \\
\hline $1.6-2.0$ & -0.25 & -0.47 & -0.22 \\
\hline $0.8-1.6$ & 0.54 & 0.58 & 0.42 \\
\hline $0-0.8$ & 1.05 & 0.22 & 0.74 \\
\hline$<0$ & 2.40 & -0.31 & 1.62 \\
\hline Totals & 3.74 & 0.02 & 2.56 \\
\hline
\end{tabular}

\section{Conclusions}

This array of current meters across the southern boundary of the Brazil Basin generally supports the classical notions of flow within the three major water masses of the subthermocline regime (Fig. 4). Antarctic Intermediate Water, the shallowest of the three, flows west and southward in the region as part of the anticyclonic, subtropical, wind-driven circulation. Consequently, near the western boundary at least, its sense of flow is toward its source, which adds to the transport of the Brazil Current. Directly beneath, the North Atlantic Deep Water flows southward across the array but shows some influence of the bottom relief with guidance by the Vema Channel and a shallow depression over the Santos Plateau. Antarctic Bottom Water enters the Brazil Basin most voluminously through the Vema Channel but also in significant quantities farther east in the Hunter Channel. The depression on the Santos Plateau has an even more pronounced effect on the AABW than on the NADW, causing some recirculation of water that had entered through the Vema Channel. The penetration of the southward flowing Brazil Current to the bottom splits the northward transport of AABW over the Santos

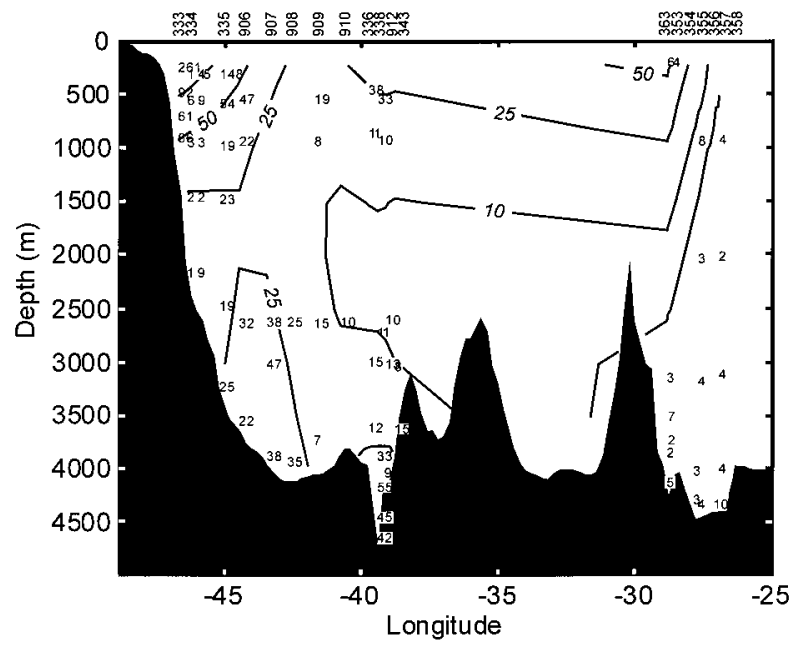

FIG. 7. Sectional view of the eddy kinetic energy in $\mathrm{cm}^{2} \mathrm{~s}^{-2}$. 


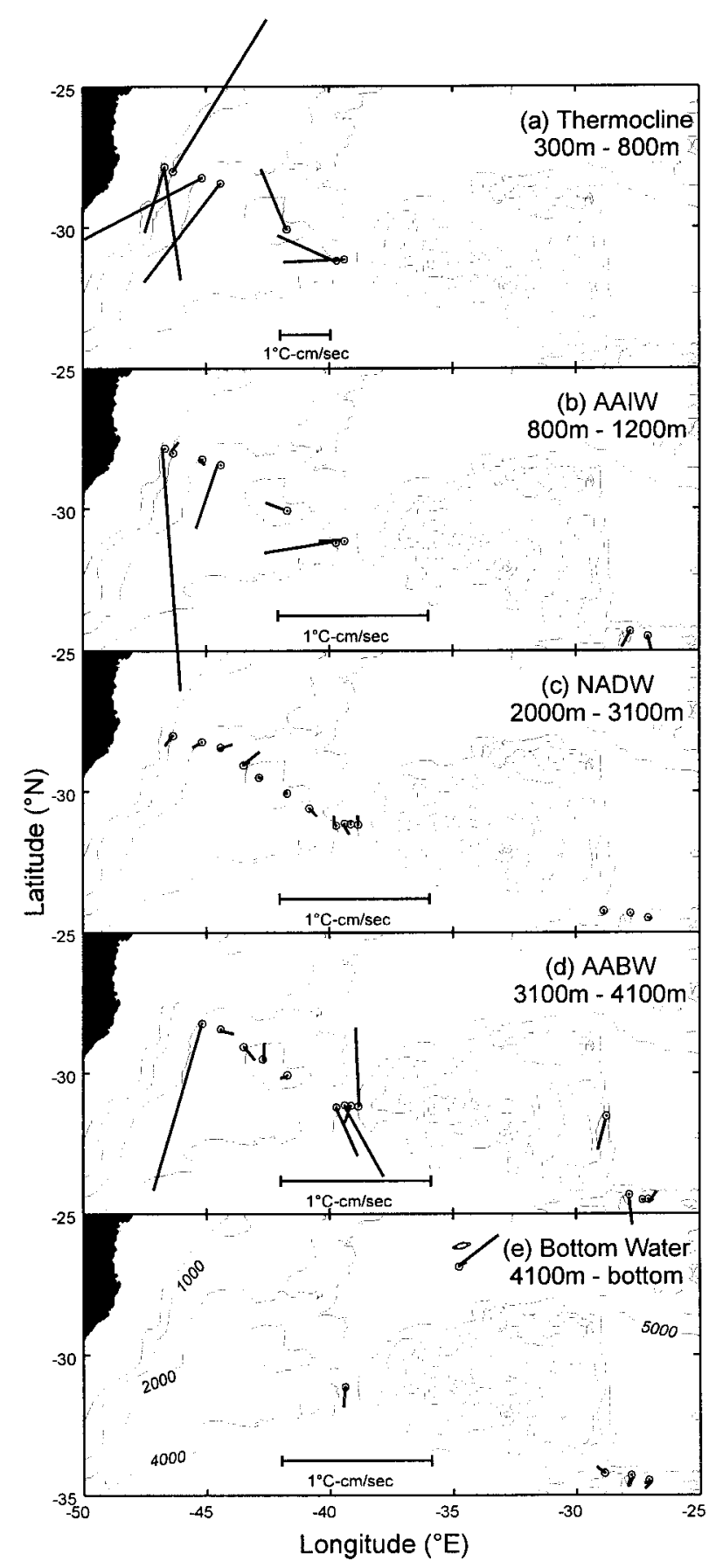

FIG. 8. As in Fig. 4 except for the eddy temperature flux.

Plateau. Total transport of AABW into the Brazil Basin remains close to the $6.7 \mathrm{~Sv}$ estimated by Speer and Zenk (1993) but is differently partitioned between the Santos Plateau (0 Sv vs $2 \mathrm{~Sv}$ ) and the Hunter Channel (2.9 Sv vs $0.7 \mathrm{~Sv}$ ) with that through the Vema Channel remaining at $4.0 \mathrm{~Sv}$ with our method.

The question of how much AABW flows into the Brazil Basin is particularly important because there are
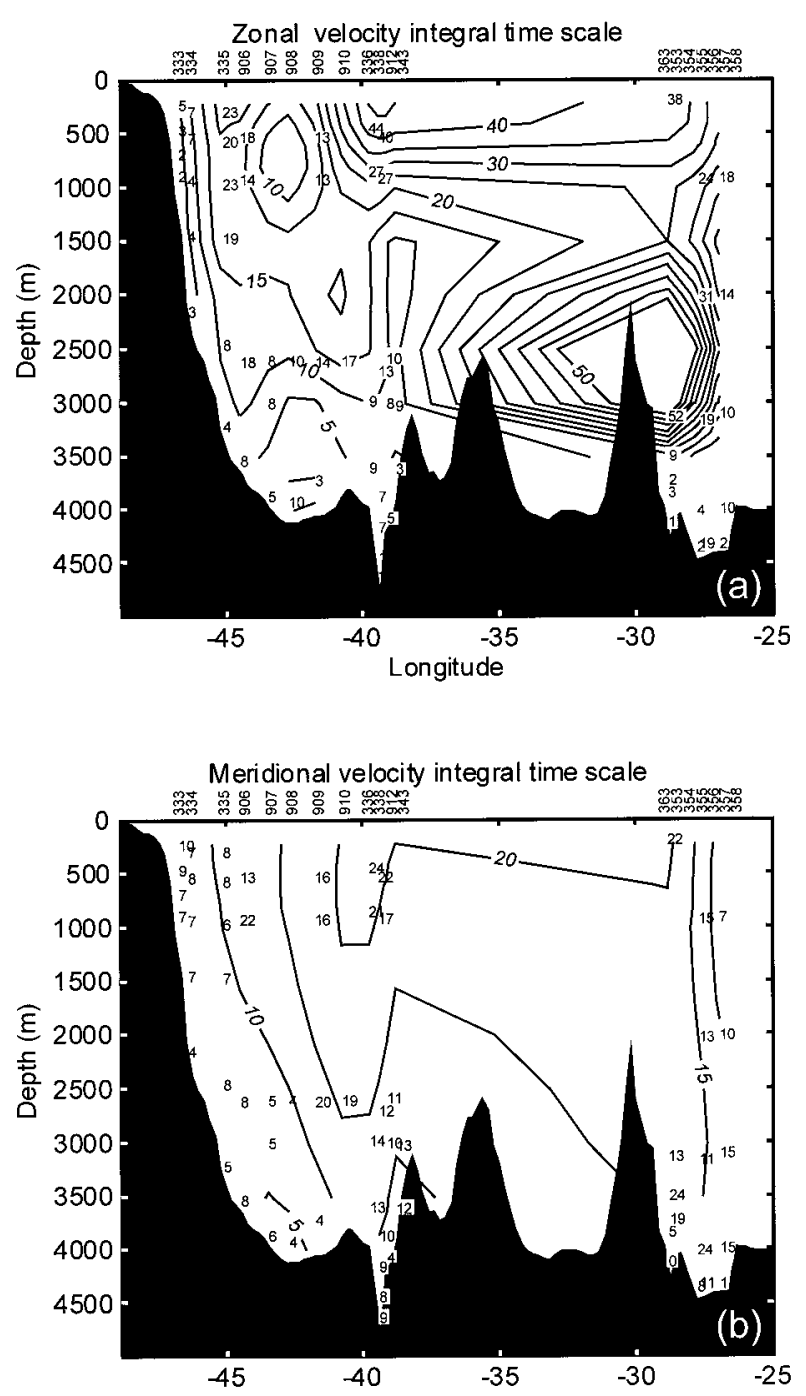

FIG. 9. Integral timescale, in days, for the (a) zonal and (b) meridional components of velocity as calculated from the integral of the autocorrelation function from zero lag to the lag corresponding to the first zero crossing.

only two exits and accurate determination of the mass and heat balances permits an estimation of the eddy heat flux across the upper boundary of the AABW (Hogg et al. 1982). This, in turn, yields an estimate of the basinaveraged cross-isothermal diffusivity, which Hogg et al. calculated to be $1-5 \mathrm{~cm}^{2} \mathrm{~s}^{-1}$. Recent measurements at the two exits have given a loss of 2-2.6 Sv to the western North Atlantic through an equatorial passage near $35^{\circ} \mathrm{W}$ (Hall et al. 1997) and 1.2 Sv to the eastern North Atlantic through the Romanche and Chain Fracture Zones in the Mid-Atlantic Ridge, also close to the equator (Mercier and Speer 1998). The combination of these estimates leaves a net of about 3-4 Sv to upwell across the interface between NADW and AABW, not much different from the number used by Hogg et al. (1982). Polzin et al. (1997) have compelling evidence from mi- 
crostructure measurements that this mixing takes place preferentially over the fractured western flank of the Mid-Atlantic Ridge and not over the smoother middle basin.

The eddy field (Fig. 7) is generally weak in this area although it intensifies westward toward the Brazil Current in a manner analogous to the region of the North Atlantic before the Gulf Stream has separated from the coast. Associated integral timescales (Fig. 8) are also similar to the North Atlantic being in the range of 515 days with shorter timescales near the boundary and longer ones in the interior and in the upper ocean.

Acknowledgments. This is a WOCE contribution. The authors wish to thank the officers and crew of the F.S. Meteor for their considerable help during three cruises, as well as the able assistance of the mooring groups at IfM Kiel and WHOI. We have benefited from discussions with J. Holfort and B. Lenz and the careful scrutiny by two anonymous reviewers. This work was financially supported by Deutsche Forschungsgemeinschaft (Si 111/38-1, Si 111/39-1); Bundesministerium für Bildung, Wissenschaft, Forschung und Technologie (03F0535A, 03F0050D); and the U.S. National Science Foundation (OCE-90-04396 and OCE-94-15509).

\section{REFERENCES}

Boebel, O., C. Schmid, and W. Zenk, 1997: Flow and recirculation of Antarctic Intermediate Water across the Rio Grande Rise. $J$. Geophys. Res., 102, 20 967-20 986.

Burkle, L. H., and P. E. Biscaye, 1971: Sediment transport by Antarctic Bottom Water through the eastern Rio Grande Rise. Geol. Soc. Amer. Abstr. Programs, 3, 518-519.

Hall, M. M., M. McCartney, and J. A. Whitehead, 1997: Antarctic Bottom Water flux in the equatorial Western Atlantic. J. Phys. Oceanogr., 27, 1903-1926.

Hogg, N. G., 1983: Hydraulic control and flow separation in a multilayered fluid with applications to the Vema Channel. J. Phys. Oceanogr., 13, 695-708.

-, and W. Zenk, 1997: Long period changes in the bottom water flowing through Vema Channel. J. Geophys. Res., 102, 15 63915646 .

—, P. Biscaye, W. Gardner, and W. J. Schmitz Jr., 1982: On the transport and modification of Antarctic Bottom Water in the Vema Channel. J. Mar. Res., 40 (Suppl.), 231-263.

- W. B. Owens, G. Siedler, and W. Zenk, 1996: Circulation in the Deep Brazil Basin. The South Atlantic: Present and Past
Circulation, G. Wefer, W. H. Berger, G. Siedler, and D. Webb, Eds., Springer-Verlag, 249-260.

Holfort, J., 1994: Großräumige Zirkulation und meridionale Transporte im Südatlantik. Ber. Inst. Meeresk. Kiel, 260, 95.

Lenz, B., 1997: Bodenwassertransporte über die Rio-Grande-Schwelle. Diplom thesis, Kiel University, 68 pp. [Available from Library, Christian-Albrechts-Universität, D-24098 Kiel, Germany.]

Mercier, H., and K. G. Speer, 1998: Transport of bottom water in the Romanche Fracture Zone and the Chain Fracture Zone. J. Phys. Oceanogr., 28, 779-790.

Müller, T. J., Y. Ikeda, N. Zangenberg, and L. V. Nonato, 1998: Direct measurements of western boundary currents off Brazil. J. Geophys. Res., in press.

Pätzold, J., K. Heidland, W. Zenk, and G. Siedler, 1996: On the bathymetry of the Hunter Channel. The South Atlantic: Present and Past Circulation, G. Wefer, W. H. Berger, G. Siedler, and D. Webb, Eds., Springer-Verlag, 355-361.

Polzin, K. L., J. M. Toole, J. R. Ledwell, and R. W. Schmitt, 1997: Spatial variability of turbulent mixing in the abyssal ocean. Science, 276, 93-96.

Rintoul, S. R., 1991: South Atlantic interbasin exchange. J. Geophys. Res., 96, 2675-2692.

Roemmich, D., S. Hautala, and D. Rudnick, 1996: Northward abyssal transport through the Samoan passage and adjacent regions. $J$. Geophys. Res., 101, 14 039-14 055.

Saunders, P. M., 1987: Flow through Discovery Gap. J. Phys. Oceanogr., 17, 631-643.

Spall, M. A., 1994: Wave-induced abyssal recirculations. J. Mar. Res., 52, 1051-1080.

Speer, K., and W. Zenk, 1993: The flow of bottom water into the Brazil Basin. J. Phys. Oceanogr., 23, 2667-2682.

— - W. Zenk, G. Siedler, J. Pätzold, and C. Heidland, 1992: First resolution of flow through the Hunter Channel in the South Atlantic. Earth Planet. Sci. Lett., 113, 287-292.

Tarbell, S., R. Meyer, N. Hogg, and W. Zenk, 1994: A moored array along the southern boundary of the Brazil Basin for the Deep Basin Experiment-Report on a joint experiment 1991-1992. Woods Hole Oceanogr. Inst. Tech. Rep. WHOI-94-07 and Berichte aus dem Institut für Meereskunde an der Christian-Albrechts-Universität-Kiel 243, 107 pp.

Whitehead, J. A., and L. V. Worthington, 1982: The flux and mixing rates of Antarctic Bottom Water within the North Atlantic. $J$. Geophys. Res., 87, 7903-7924.

Zemba, J. C., 1991: The structure and transport of the Brazil Current between $27^{\circ}$ and $36^{\circ} \mathrm{S}$. PhD. Thesis, MIT/WHOI Joint Program in Oceanography and Oceanographic Engineering, $160 \mathrm{pp}$.

Zenk, W., and T. J. Müller, 1995: WOCE Studies in the South Atlantic, Cruise No. 28, 29 March-14 June 1994. Rep. 95-1, MeteorBerichte, Universität Hamburg, 193 pp. [Available from Library, Christian-Albrechts-Universität, D-24098 Kiel, Germany.]

— flowing into the Brazil Basin. Deep-Sea Res. I, 43, 1461-1473.

, M. Vanicek, D. Carlsen, and A. Pinck, 1996: Hydrographic observations. Report and Preliminary Results of Meteor Cruise M34/3, Walvis Bay-Recife, 21.2.-17.3.1996, G. Wefer, and cruise participants, Eds., University of Bremen, 167 pp. 